\title{
DNA Damage and Augmented Oxidative Stress in Bone Marrow Mononuclear Cells from Angiotensin-Dependent Hypertensive Mice
}

\author{
Bianca P. Campagnaro, ${ }^{1}$ Clarissa L. Tonini, ${ }^{1}$ Breno V. Nogueira, ${ }^{1,2}$ Dulce E. Casarini, ${ }^{3}$ \\ Elisardo C. Vasquez, ${ }^{1,4}$ and Silvana S. Meyrelles ${ }^{1}$ \\ ${ }^{1}$ Laboratory of Transgenes and Cardiovascular Control, Department of Physiological Sciences, Health Sciences Center, \\ Federal University of Espirito Santo, Avenida Marechal Campos 1468, 29043-900 Vitoria, ES, Brazil \\ ${ }^{2}$ Department of Morphology, Health Sciences Center, Federal University of Espirito Santo, 29045-402 Vitoria, ES, Brazil \\ ${ }^{3}$ Department of Nephrology, Federal University of Sao Paulo (UNIFESP), 04021-001 Sao Paulo, SP, Brazil \\ ${ }^{4}$ College of Health Sciences, EMESCAM, 29043-900 Vitoria, ES, Brazil
}

Correspondence should be addressed to Silvana S. Meyrelles; meyrelle.vix@terra.com.br

Received 26 November 2012; Accepted 16 January 2013

Academic Editor: Nicolas Federico Renna

\begin{abstract}
Copyright (C) 2013 Bianca P. Campagnaro et al. This is an open access article distributed under the Creative Commons Attribution License, which permits unrestricted use, distribution, and reproduction in any medium, provided the original work is properly cited.

It has been proposed that the nonhemodynamic effects of angiotensin II are important for the damage observed in the two-kidney, one-clip (2K1C) renovascular hypertension model. Much evidence confirms that angiotensin II is directly involved in NAD(P)H oxidase activation and consequent superoxide anion production, which can damage DNA. The current study was performed to examine the effects of angiotensin-II-dependent hypertension in bone marrow mononuclear cells (BM-MNC); dihydroethidium staining was used to assess reactive oxygen species (ROS) production, and the comet assay was used to assess DNA fragmentation in $2 \mathrm{~K} 1 \mathrm{C}$ hypertensive mice 14 days after renal artery clipping. In this study we demonstrated that $2 \mathrm{~K} 1 \mathrm{C}$ hypertensive mice have an elevated lymphocyte count, while undifferentiated BM-MNC counts were diminished. 2K1C mice also showed an augmented ROS production and marked BM-MNC DNA fragmentation. In conclusion, endogenous renin angiotensin system activation-induced arterial hypertension is characterized by excessive ROS production in BM-MNC, which might cause marked DNA damage.
\end{abstract}

\section{Introduction}

High blood pressure is commonly found in patients with chronic kidney disease and renovascular hypertension is a common form of secondary hypertension and frequently resistant to pharmacologic treatment [1]. In the two-kidney, one clip (2K1C) Goldblatt model, renovascular hypertension is induced by unilateral renal artery stenosis, which reduces renal perfusion of the clipped kidney and causes increased renin release and circulating angiotensin II (Ang II) [2]. Ang II, which is the main effector peptide of the renin-angiotensin system (RAS), has marked hemodynamic, cardiac, and renal effects, as previously observed by our laboratory in mice [25]. In addition, it also exerts tissue-specific responses as it can be locally synthesized [6-8]. Although it is controversial, the existence of a local bone marrow (BM) RAS has been demonstrated in rats [9]. Because the BM is a highly organized, complex organ, that is, the principal hematopoietic tissue in adults, locally BM-formed Ang II may be an autocrine or paracrine peptide that affects physiological and pathological hematopoiesis [10].

Studies have demonstrated that Ang II plays a role in oxidative stress development in the spontaneously hypertensive rat [11] and in the renovascular hypertensive rat [12]. Reactive oxygen species (ROS) play a crucial role in RAS signaling in BM cells $[9,13]$. In addition, studies in experimental animals have shown that augmented ROS [14-16], particularly superoxide $\left(\cdot \mathrm{O}_{2}{ }^{-}\right)[17-20]$, can interact 
with DNA, which results in oxidative damage and DNA fragmentation-mediated cellular injury [21].

Taken together, this evidence strongly supports the importance of the $2 \mathrm{~K} 1 \mathrm{C}$ murine experimental model to investigate the influence of hypertension on DNA damage. Therefore, in the present study, we tested the hypothesis that $2 \mathrm{~K} 1 \mathrm{C}$-mediated hypertension increases ROS production and induces DNA damage in murine BM mononuclear cells (MNC).

\section{Material and Methods}

2.1. Animals. Experiments were performed in male C57BL/6 (C57) mice, which present a single renin gene [22], weighing $23 \mathrm{~g}$ on average, and that were bred and maintained in the Laboratory of Transgenes and Cardiovascular Control animal facility (Vitoria, ES, Brazil). The mice were fed a standard chow diet and provided water ad libitum. Animals were housed in individual plastic cages with controlled temperature $\left(22^{\circ} \mathrm{C}\right)$ and humidity $(60 \%)$ and were exposed to a $12: 12 \mathrm{~h}$ light-dark cycle. All of the experimental procedures were performed in accordance with the National Institutes of Health (NIH) guidelines, and study protocols were previously approved by the Institutional Animal Care and Use Committee (CEUA-Emescam Protocol no. 010/2009).

2.2. Induction of 2 K1C Renovascular Hypertension. We used a mouse model of $2 \mathrm{~K} 1 \mathrm{C}$ angiotensin-dependent hypertension, as previously described $[3,4,23]$. Briefly, the animals were anesthetized (ketamine/xylazine 91/9.1 mg/kg, i.p.) and kept on a heating pad that maintained the body temperature at $37^{\circ} \mathrm{C}$ to avoid hypothermia. The left renal artery was exposed through a retroperitoneal flank incision and was carefully isolated from the renal vein, nerves, and connective tissues. A U-shaped stainless steel clip with a $0.12 \mathrm{~mm}$ opening width was placed around the renal artery close to the abdominal aorta, which resulted in partial renal perfusion occlusion [24]. The wound was sutured, and the animal received a single injection of benzylpenicillin benzathine $(7 \mathrm{mg} / \mathrm{kg}, i . \mathrm{m}$. $)$ followed by recovery under care for $24 \mathrm{~h}$. Control mice underwent the same surgical procedure except for the renal artery clip placement (Sham).

2.3. Hemodynamic Measurements. Fourteen days after the renal artery clipping $(2 \mathrm{~K} 1 \mathrm{C})$ or Sham operations, the animals were anesthetized with a combination of ketamine/xylazine (91/9.1 mg/kg, i.p.) and the right common carotid artery was exposed and isolated through a cervical incision. A catheter $(0.040 \mathrm{~mm}$ OD $\times 0.025 \mathrm{~mm}$ ID; Micro-Renathane; Braintree Scientific) was filled with heparin solution (50 UI/mL saline) and prior to insertion into the right carotid artery, which was subcutaneously tunneled and brought out at the nape of the neck. Immediately after surgery, animals received a single benzylpenicillin benzathine $(7 \mathrm{mg} / \mathrm{kg}, i . m$.) injection. The catheter was connected to a pressure transducer (Cobe Laboratories, USA), which was plugged into a pressureprocessor amplifier and data acquisition system (MP100, Biopac Systems, USA) for mean arterial pressure (MAP) and heart rate (HR) recordings. After 48 hours, MAP and
HR direct recordings were obtained while the animals were conscious and moving around freely in their cage.

2.4. Plasma Ang II Level Measurement. After hemodynamic measurements, blood was drawn through the arterial line into tubes containing EDTA and protease inhibitor cocktail (Product no. P2714, Sigma-Aldrich); the samples were centrifuged at $9.5 \mathrm{~g}$ for $15 \mathrm{~min}$ in a refrigerated centrifuge $\left(4^{\circ} \mathrm{C}\right)$ to remove plasma for later analysis. Plasma Ang II was quantified by reverse phase high-performance liquid chromatography (HPLC). Briefly, peptides were initially separated in a reverse phase Aquapore ODS 300 column $7 \mu \mathrm{m}(4.6 \times$ $250 \mathrm{~mm}$ ) (Applied Biosciences, Foster City, CA, USA) using a linear mobile phase gradient from 5 to $35 \%$ (acetonitrile in $0.1 \%$ phosphoric acid) for $40 \mathrm{~min}$ using a $1.5 \mathrm{~mL} / \mathrm{min}$ flow rate. Ang III (320 ng) was added to each sample as an internal standard, and the peptides were detected at $214 \mathrm{~nm}$ absorbance. Ang II was extracted using Sep-PackC18 column chromatography (Millipore, MA, USA) and was activated with $5 \mathrm{~mL}$ methanol, $5 \mathrm{~mL}$ tetrahydrofuran, $5 \mathrm{~mL}$ hexane, and $10 \mathrm{~mL} \mathrm{H}_{2} \mathrm{O}$ (MilliQ). After activation, the samples were run through the column and eluted with ethanol: acetic acid: $\mathrm{H}_{2} \mathrm{O}(90: 4: 6, \mathrm{v} / \mathrm{v})$. The last phase eluate containing Ang II was evaporated in a Speed Vac SC 110 (Savant Instruments, Holbrook, NY, USA) and reconstituted with $500 \mu \mathrm{L} 0.1 \%$ phosphoric acid in $5 \%$ acetonitrile, filtered, and injected onto the HPLC analytical column. Retention time was used to identify peaks of interest, which had been previously determined by standard peptide elution. The calculations were based on peak area, and Ang II concentration was expressed as $\mathrm{pmol} / \mathrm{mL}$ blood.

2.5. Bone Marrow Mononuclear Cell Isolation. Mice were euthanized with a sodium thiopental overdose $(100 \mathrm{mg} / \mathrm{kg}$, i.p.) and marrow samples were collected from femurs and tibias that had been dissected and cleaned of all soft tissues. After removing the epiphyses and gaining access to the marrow cavities, whole BM was flushed out using a 26gauge needle attached to a $1 \mathrm{~mL}$ syringe filled with Dulbecco's Modified Eagle Medium (DMEM; Sigma, St. Louis, MO, USA). MNCs were isolated by density-gradient centrifugation; the BM suspension in $4 \mathrm{~mL}$ DMEM was loaded on $4 \mathrm{~mL}$ Histopaque 1083 (Sigma-Aldrich) and centrifuged for $30 \mathrm{~min}$ at $400 \mathrm{~g}$. The BM-MNC fraction was subsequently collected and washed in phosphate-buffered saline (PBS). A small volume of the resulting suspension was mixed with $0.4 \%$ trypan blue to perform cell count and viability analysis. Lymphocytes and undifferentiated cells were analyzed using a Neubauer chamber.

2.6. DNA Damage Measurement with the Comet Assay. Bone marrow MNC DNA damage was analyzed by the alkaline comet assay as described by Singh et al. [25] with minor modifications. Regular microscope slides were precoated with $200 \mu \mathrm{L} 1.5 \%$ normal melting point agarose in distilled water, at $60^{\circ} \mathrm{C}$ (Sigma-Aldrich), dried overnight at room temperature, and then stored at $4^{\circ} \mathrm{C}$ until use. Subsequently, $2 \times 10^{4}$ MNCs were mixed with $100 \mu \mathrm{L} 1 \%$ low melting point agarose in $\mathrm{PBS}$ at $37^{\circ} \mathrm{C}$ (Invitrogen, Spain) and spread on 
the agarose-coated slides using a coverslip. After gelling at $4^{\circ} \mathrm{C}$ for $20 \mathrm{~min}$, coverslips were removed, and the slides were immersed in freshly prepared cold lysis solution $(2.5 \mathrm{M} \mathrm{NaCl}$, $100 \mathrm{mM}$ EDTA, $10 \mathrm{mM}$ Tris at $\mathrm{pH}$ 10-10.5, with freshly added $1 \%$ Triton X-100 and $10 \%$ DMSO) at $4^{\circ} \mathrm{C}$ for $1 \mathrm{~h}$. After a 5 min wash in cold distilled water, the slides were placed in an electrophoresis chamber, which was then filled with fresh alkaline buffer ( $300 \mathrm{mM} \mathrm{NaOH}, 1 \mathrm{mM}$ EDTA, $\mathrm{pH}>13)$ for $20 \mathrm{~min}$ at $4^{\circ} \mathrm{C}$. Electrophoresis was performed at $300 \mathrm{~mA}$ and $25 \mathrm{~V}$ for $30 \mathrm{~min}$. All of these steps were conducted without direct light to prevent additional DNA damage. The slides were washed three times for 5 min with $0.4 \mathrm{M}$ Tris buffer, $\mathrm{pH}$ 7.5 , for neutralization. Finally, $100 \mu \mathrm{L} 20 \mu \mathrm{g} / \mathrm{mL}$ of ethidium bromide (Sigma-Aldrich) was added to each slide, covered with a coverslip, and analyzed at a 20x magnification using a fluorescence microscope (Olympus BX60, United Kingdom) that had been equipped with excitation $(510-550 \mathrm{~nm})$ and barrier $(590 \mathrm{~nm})$ filters.

DNA damage was evaluated using visual classification of comets into five levels according to comet tail size from 0 (undamaged with no tail) to 4 (maximally damaged with long tail). The DNA damage extent was expressed in arbitrary units (a.u.). Three hundred randomly selected cells (100 cells from each of three replicate slides) were analyzed from each animal, and three AU values were generated for each animal, which were averaged to obtain the final result per animal. The group damage index (DI) ranged from 0 , in which all of the cells were undamaged ( 300 cells $\times 0$ ), to 1200 , in which all of the cells were maximally damaged $(300$ cells $\times 4)$ [26]. The damage frequency (\%) was calculated based on the number of cells with tails versus those without tails [27] and the \% DNA damage was the fraction of each damage level relative to all of the comets that were analyzed.

2.7. Intracellular Superoxide Anion Fluorescence Measurement. Nonfluorescent dihydroethidium (DHE) was used for intracellular $\bullet \mathrm{O}_{2}{ }^{-}$detection by flow cytometry. Hydroethidine is freely cell permeable and is rapidly oxidized by superoxide to ethidium, which binds to DNA and amplifies the red fluorescence signal. To estimate the $\bullet \mathrm{O}_{2}{ }^{-}$content in the cell suspension, $10^{5} \mathrm{BM}-\mathrm{MNCs}$ were stained with $160 \mu \mathrm{M}$ DHE, followed by a $30 \mathrm{~min}$ incubation at $37^{\circ} \mathrm{C}$ in the dark to facilitate dye loading. DHE-loaded cells were treated with $10 \mathrm{mM} \mathrm{H}_{2} \mathrm{O}_{2}$ to oxidize the dye as a positive control. After 5 min of $\mathrm{H}_{2} \mathrm{O}_{2}$ treatment, the BM-MNCs were washed with PBS and cellular ROS levels were analyzed immediately with a FACSCanto II flow cytometer (Becton Dickinson, San Juan, CA, USA). Ten thousand events were recorded from each sample, and forward and side scatter gates were used to select single cells from clumps and debris. Specific fluorescence intensity was expressed as the median fluorescence intensity from the average of at least three repeated experiments in a.u. Red fluorescence was detected between 564 and $606 \mathrm{~nm}$ using a 585/42 bandpass filter. The Data were acquired and analyzed using BD FACSDiva software (BD).

2.8. Statistical Analysis. The data are presented as representative figures or as the means \pm SEM. The flow cytometry data are expressed as median fluorescence intensity
TABLE 1: Body, ventricular, and kidney weights of 2K1C and Sham mice 14 days after renal artery clipping.

\begin{tabular}{lcc}
\hline Parameters & $\begin{array}{c}\text { Sham } \\
(5)\end{array}$ & $\begin{array}{c}2 \mathrm{~K} 1 \mathrm{C} \\
(5)\end{array}$ \\
\hline Body weight (g) & $24 \pm 0.5$ & $22 \pm 0.8^{*}$ \\
Ventricular dry weight (mg) & $25 \pm 0.7$ & $27 \pm 0.7^{*}$ \\
Clipped kidney dry weight (mg) & $37 \pm 1.4$ & $25 \pm 4.2^{*}$ \\
Contralateral kidney dry weight (mg) & $40 \pm 2.0$ & $44 \pm 1.7$ \\
$\begin{array}{l}\text { Clipped kidney weight/unclipped } \\
\text { kidney weight (mg/mg) }\end{array}$ & $0.94 \pm 0.02$ & $0.56 \pm 0.09^{* *}$ \\
\hline
\end{tabular}

Values are the means \pm SEM. ${ }^{*} P<0.05$ and ${ }^{* *} P<0.01$ compared with the Sham animals (student's $t$-test for independent samples).

(MFI) \pm coefficient of variation (CV) of 3 repeated and statistically reproducible (Friedman test) measurements of at least five independent animals. Normality was evaluated using the Kolmogorov-Smirnov test. Statistical analysis was performed using Student's $t$-test for comparison of two independent groups, and two-way analysis of variance (Anova) followed by the Bonferroni's post hoc test was used for comparison of more than 2 groups. The Mann-Whitney test was used to compare the rank sum for the MFIs from the oxidative stress experiments. $P$ values $<0.05$ were considered to be statistically significant.

\section{Results}

3.1. Body, Heart, and Kidney Weights, Blood Pressure, Heart Rate, and Plasma Ang II. Initial body weight was statistically similar among the groups. At the end of the experiments, body weight was reduced and ventricular weight was increased in the hypertensive group compared with the Sham group (Table 1). The hypertensive group also showed a significant increase in ventricular weight compared with the Sham group. Fourteen days after clip application, the left kidney was atrophic, while the right kidney displayed compensatory hypertrophy in the $2 \mathrm{~K} 1 \mathrm{C}$ mice.

Figure 1 shows the average values of direct resting MAP and HR measurements in conscious animals 14 days after renal artery clipping. As expected, MAP was $40 \%$ higher $(P<$ 0.01 ) in the 2K1C than in the Sham mice. Hypertension in the $2 \mathrm{~K} 1 \mathrm{C}$ mice was accompanied by tachycardia when compared with the Sham mice. Plasma Ang II concentration was 4.5fold greater $(P<0.01)$ in the $2 \mathrm{~K} 1 \mathrm{C}$ than in the Sham mice as measured by HPLC.

3.2. Bone Marrow Mononuclear Cells Analysis. We first assessed the effect of Ang II-dependent hypertension on BMMNC viability and number using a Neubauer chamber after BM separation with a density gradient. Cell viability was assessed using the trypan blue exclusion method, and no differences were found between the groups (Sham: $97 \pm 0.54 \%$ versus 2K1C: $96 \pm 0.54 \%)$. To investigate whether the MNC number was reduced in the $2 \mathrm{~K} 1 \mathrm{C}$ mice compared with the Sham mice, we quantified lymphocytes and undifferentiated cells. As shown in Figure 2, the 2K1C mice had increased 


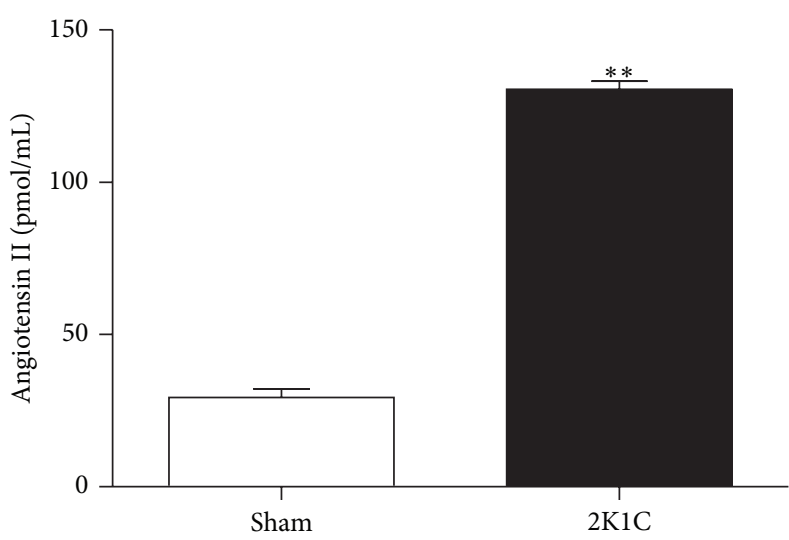

(a)

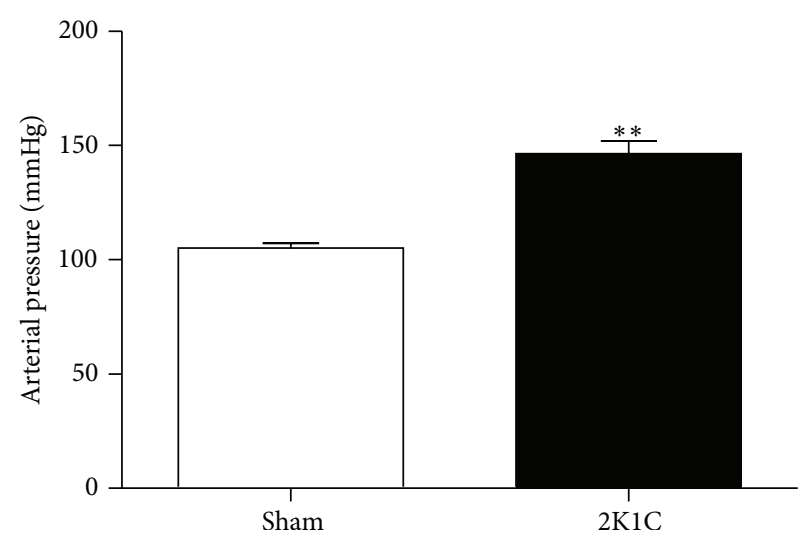

(b)

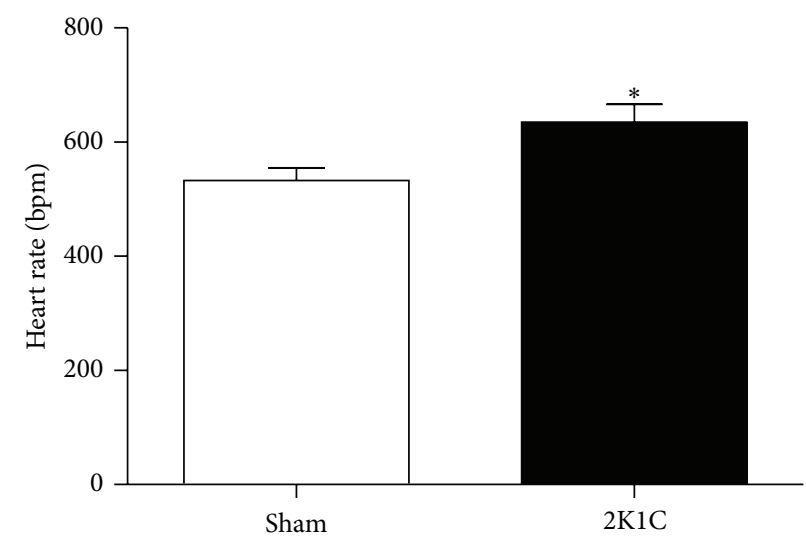

(c)

Figure 1: Bar graphs demonstrating resting mean arterial pressure, heart rate, and plasma angiotensin II values in conscious Sham $(n=5)$ and renovascular hypertensive $(2 \mathrm{~K} 1 \mathrm{C}, n=5)$ mice. Values are the means \pm SEM. ${ }^{*} P<0.05$ and ${ }^{* *} P<0.01$ versus the Sham group (Student's $t$ test for independent samples).

lymphocyte counts $(62 \%)$ with a simultaneous reduction in undifferentiated cell number (18\%) compared with the control animals.

3.3. DNA Damage Measurement with the Comet Assay. The comet assay is a versatile and sensitive method for quantifying and analyzing DNA fragmentation in individual cells that can be used to assess oxidative DNA damage. The basic principle of the comet assay is DNA electrophoresis in an agarose matrix. Because the fragmented DNA migrates, the cells look like a comet under microscope with a head containing intact DNA and a tail containing DNA fragments [24]. Genomic DNA fragmentation incidence was visually analyzed according to comet appearance. To elucidate Ang II-dependent hypertension effects on BM-MNC, DNA damage was scored into five classes according to tail size and the relative tail DNA content indicates the amount of DNA damage. A significant predominance of low genotoxicity levels 0 and 1 in the Sham animals (level 0:28 \pm 3.4 and level 1: $40 \pm 2.4 \%$ ) compared with the $2 \mathrm{~K} 1 \mathrm{C}$ mice (level 0:7 \pm 4.4 and level 1: $7 \pm 1 \%$ ) was observed. In contrast, severe genotoxicity levels 3 and 4 prevailed in the 2K1C mice (level 3: $36 \pm 3.2$ and level 4: $27 \pm 6 \%$ ) compared with the Sham mice (level 3: $7 \pm 0.4 \%$ and level 4: $2 \pm 0.4 \%$ ). Genotoxicity levels are demonstrated as typical images and average values in Figure 3. Moreover, DNA fragmentation was quantified using the DNA damage index and frequency (Figures 3(a) and 3(b)). The 2K1C mice had increased DNA damage as indicated by a higher damage index (Sham: $345 \pm$ 19 versus $2 \mathrm{~K} 1 \mathrm{C}: 806 \pm 55$ a.u.) and frequency (Sham: $72 \pm 3 \%$ versus $2 \mathrm{~K} 1 \mathrm{C}: 93 \pm 4 \%$ ).

3.4. Ang II-Dependent Hypertension Induced ROS Production. The above findings led us to further investigate the effects of Ang II-dependent hypertension on ROS production in BM-MNC. DHE is a membrane-permeable blue fluorescent dye that rapidly accumulates in the cytoplasm, where it is oxidized by $\cdot \mathrm{O}_{2}{ }^{-}$, resulting in red nuclear fluorescence that can be measured by flow cytometry. In Figure 4, representative histograms (Figure 4(a)) and average (bar graphs) $\bullet \mathrm{O}_{2}{ }^{-}$ production values are shown. As demonstrated by the right shift and in the bar graph, DHE median fluorescence intensity (MFI) values were significantly higher in the $2 \mathrm{~K} 1 \mathrm{C}$ than in the Sham group (16856 \pm 5809 versus $2051 \pm 336$ a.u., $P<0.01)$, indicating increased intracellular BM-MNC oxidative stress. 


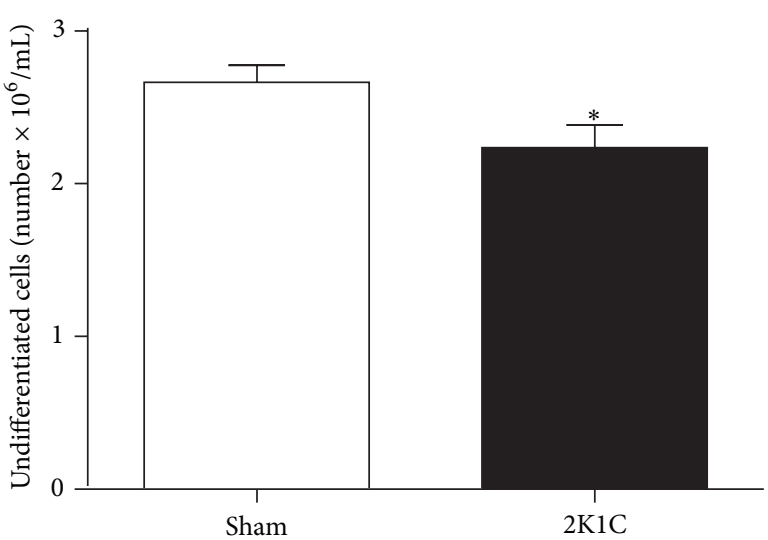

(a)

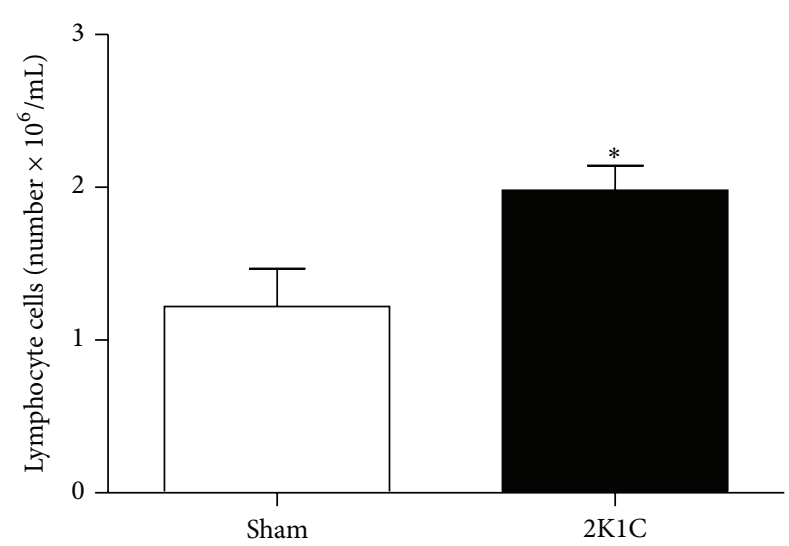

(b)

FIGURE 2: Neubauer chamber analysis of bone marrow mononuclear cells from Angiotensin-II-dependent hypertensive $(2 \mathrm{~K} 1 \mathrm{C}, n=10)$ and normotensive (Sham, $n=10$ ) mice. Values of lymphocytes and undifferentiated cells are the means \pm SEM. ${ }^{*} P<0.05$ versus Sham group (Student's $t$ test for independent samples).

\section{Discussion}

The main finding of this study was marked DNA fragmentation in BM-MNC from Ang II-dependent hypertensive mice, most likely because of augmented $\bullet \mathrm{O}_{2}{ }^{-}$production and consequent oxidative stress. Further studies including other experimental models should be designed to discriminate the relative influence of hypertension and Ang II on this process.

Renal artery clipping is accompanied by activation of the RAS and hemodynamic alterations [14, 28-30]. Higher levels of plasma renin and Ang II in 2K1C mice have been observed between 7 and 14 days after clipping and have returned to normal values by day 28 [14, 28, 30-32]. Based on these observations and on a previous publication from our laboratory [2], we performed this study two weeks after renal artery clipping. As expected, $2 \mathrm{~K} 1 \mathrm{C}$ mice showed atrophy of the clipped kidney and hypertrophy of the contralateral kidney. 2K1C mice exhibited high blood pressure levels accompanied by tachycardia, in agreement with previous studies [2, 5, 24]. In this study, we confirmed the high plasma Ang II, corroborating the concept that RAS activation plays a pivotal role in hypertension development in this murine model. In addition to the pressor and positive chronotropic effects, Ang II also stimulates cardiomyocyte protein synthesis [33-36], which in addition to hypertension may explain the cardiac hypertrophy that we observed in the $2 \mathrm{~K} 1 \mathrm{C}$ hypertensive mice. On the other hand, future studies should consider the measurement of protein levels of the ventricles as an index of hypertrophy. Taken together, these data suggest that the 2K1C mouse exhibits the main features of endogenous Ang II-dependent hypertension at this time point.

In addition to the systemic actions of the RAS, many tissues and organs have a local RAS, which can have paracrine, autocrine, and intracrine functions [37]. BM is the major reservoir for adult organ-specific stem cells, including endothelial progenitor cells (EPCs), hematopoietic stem cells (HSCs), and mesenchymal stem cells (MSCs). In this context, the presence of a complete local BM RAS that affects physiological and pathological blood cell production was hypothesized by Haznedaroglu et al. [38] and has recently been confirmed [9]. In our study, we found augmented lymphocytes and diminished numbers of undifferentiated BM cells in $2 \mathrm{~K} 1 \mathrm{C}$ hypertensive mice. Considering the presence of RAS components in HSCs [39] and stromal/MSCs [9], it is reasonable to propose that RAS may also be locally activated in BM of Ang II-dependent hypertensive mice. However, this possibility still needs to be confirmed by subsequent studies.

Accumulating evidence suggests that the local RAS is actively involved in BM cells proliferation, differentiation, and death. Of note, Ang II affects the entire BM-MNC pool, such as EPCs [40], HSCs [41, 42], and MSCs [9]. As recently demonstrated, Ang II consistently decreases the number of cultured EPCs through activation of AT1 receptors and induction of apoptosis [40]. In addition and considering that $2 \mathrm{~K} 1 \mathrm{C}$ hypertensive mice exhibit endothelial dysfunction [23], Ang II could activate inflammatory cells or cytokine production, which may be responsible for cell recruitment in inflammation [43-47]. Moreover, this vasoactive peptide directly stimulates erythropoiesis by augmenting erythropoietin hormone production [48], which regulates erythrocyte differentiation [49], through AT1 receptors [8, 41]. Accordingly, da Cunha et al. [50] and Cassis et al. [48] reported that angiotensin converting enzyme (ACE) inhibitors and AT1 receptor antagonist treatments cause anemia, demonstrating hematopoietic side effects of RAS blockers and indicating that Ang II plays an important role in hematopoiesis. Taken together, experimental evidence suggests that Ang II exhibits important hematopoietic effects by stimulating erythroid, myeloid, and lymphoid differentiation, resulting in augmented lymphocyte number and simultaneously diminished undifferentiated cell number.

There is growing evidence that increased oxidative stress, which results in excessive ROS generation, plays a role in cardiovascular diseases including hypertension, as recently reviewed by us and others [24, 51-53]. Because there is a link between ROS and RAS signaling [53-55], a key mechanism 


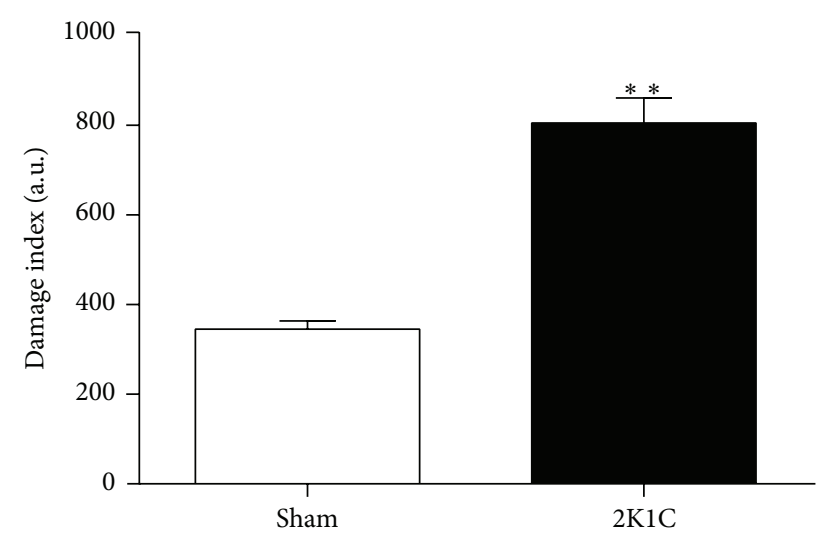

(a)

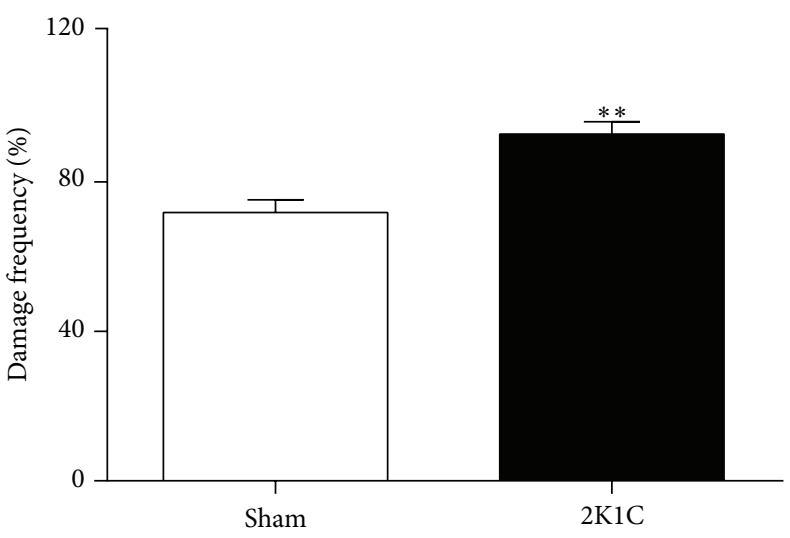

(b)
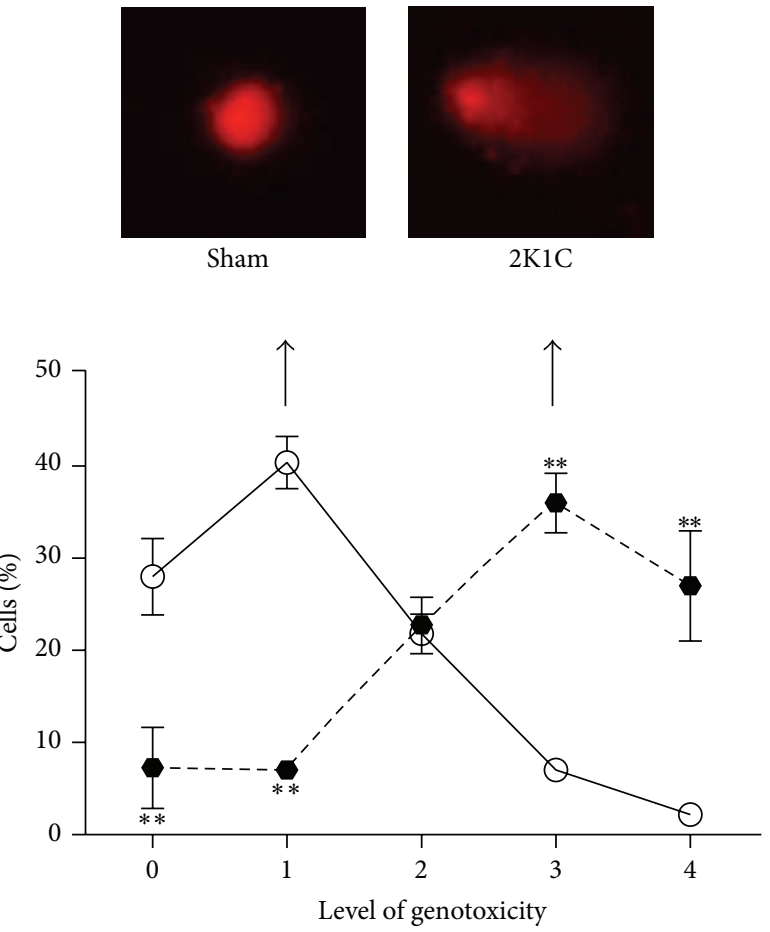

(c)

FIGURE 3: Bone marrow mononuclear cell DNA damage assessed by the comet assay. The left bar graphs demonstrate the average DNA damage index (a) and frequency (b). ${ }^{* *} P<0.01$ versus the Sham group (Student's $t$ test for independent samples). Fluorescent images (c) are typical comets demonstrating increased DNA fragmentation in a renovascular hypertensive (2K1C) mouse compared with a normotensive (Sham) mouse. The lines graph (c) demonstrates the average percentages of DNA damage percentages for each genotoxicity level, comparing the $2 \mathrm{~K} 1 \mathrm{C}$ (filled circles, $n=5$ ) with the Sham (empty circles, $n=6$ ) mice. ${ }^{* *} P<0.01$ versus the Sham group (two-way Anova). Values are the means \pm SEM.

by which Ang II influences heart and vessel function could be via its ability to activate ROS production $[24,56,57]$. We observed pronounced DHE MFI augmentation in BM$\mathrm{MNC}$ in the 2K1C hypertensive mice compared with Sham normotensive mice. The relationship between oxidative stress and increased blood pressure has been reported in many hypertensive animal models, including the SHR [58], DOCAsalt [59], the 2K1C [14], and the 1K1C [60], which have excessive $\cdot \mathrm{O}_{2}{ }^{-}$production due to augmented NAD(P)H oxidase activity [61-64]. Interestingly, in the p47phox knockout mouse with concurrent $2 \mathrm{~K} 1 \mathrm{C}$ hypertension augmented ROS production occurs via expression of this $\mathrm{NAD}(\mathrm{P}) \mathrm{H}$ oxidase subunit [14]. This enzyme can be activated by hemodynamic forces and vasoactive agonists, for example, Ang II [65-67], which is a powerful vasoconstrictor involved in hypertension pathogenesis that uses ROS as an intracellular signaling mediator [66]. In addition, it seems that Ang II induces the increase of ROS production in EPCs and that this oxidative stress accounts for the Ang II-mediated reduction of EPC number, as this effect can be blocked by cotreatment 


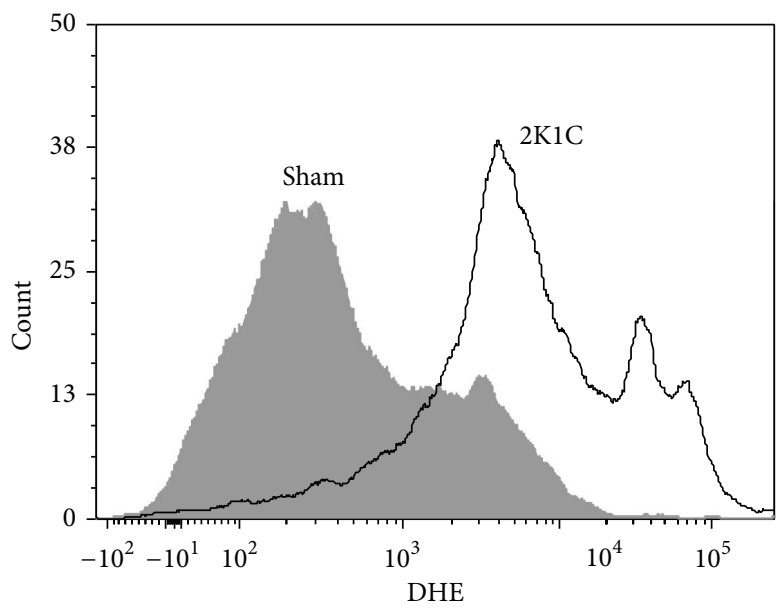

(a)

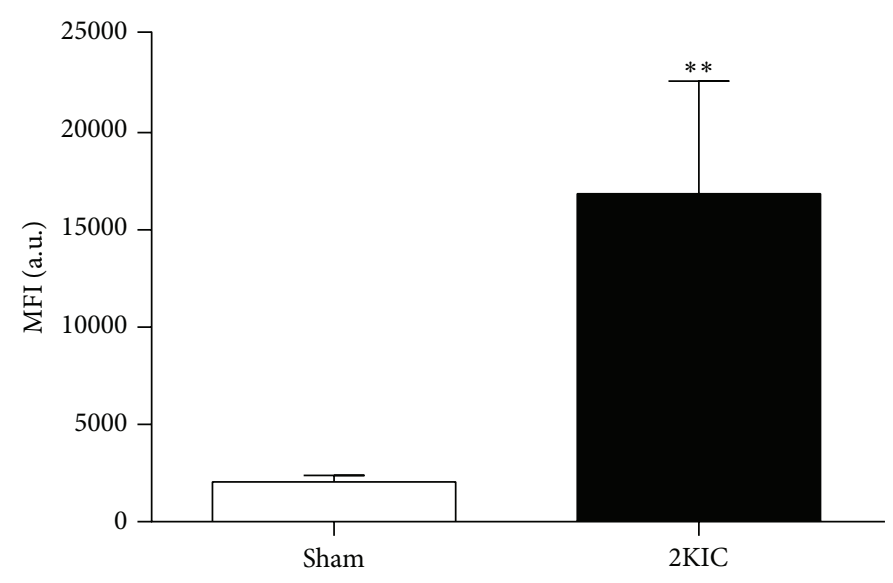

(b)

FIGURE 4: Effects of renovascular hypertension on oxidative stress in bone-marrow-mononuclear cells (BM-MNCs). (a) contains representative histograms of intracellular oxidation of dihydroethidium (DHE) to ethidium by BM-MNC from a hypertensive (2K1C) and a normotensive (Sham) mouse as evaluated by flow cytometry. The bar graph summarizes the median fluorescence intensity (MFI) values of DHE-loaded BM-MNC from 2K1C $(n=5)$ and Sham $(n=5)$ mice. Values are the medians \pm coefficient of variation. ${ }^{* *} P<0.01$ versus the Sham group (Mann-Whitney test).

with an antioxidant [40] and it increases gp91phox expression in EPCs, which may contribute to oxidative stress [68].

As discussed above, the role of Ang II goes beyond controlling circulatory homeostasis as discussed above in the impact of this peptide in ROS production, which is stimulated by $\mathrm{NAD}(\mathrm{P}) \mathrm{H}$ oxidase activation [69]. Recent experimental studies have shown that, at high concentrations, ROSs such as $\cdot \mathrm{O}_{2}{ }^{-}$are capable of direct protein and lipid oxidation, which causes DNA fragmentation [70]. DNA damage, which frequently occurs in cells exposed to oxidative stress [71], is a form of cellular injury that contributes significantly to the development and progression of cardiovascular disorders $[24,64,72]$.

The comet assay has been used to determine DNA fragmentation in blood cells in murine models of spontaneous atherosclerosis [73, 74] and renovascular hypertension [24]. However, this is the first time that the comet assay has been used to assess DNA fragmentation in BM-MNC from 2K1C mice. Our results clearly demonstrated augmented DNA fragmentation in BM-MNC from the 2K1C mice compared with the Sham mice. Augmented DNA damage has also been demonstrated in other animal models of hypertension, including kidney cells from DOCA-salt rats [75] and mouse infused with Ang II [21]. Furthermore, DNA damage caused by ROS occurs more commonly in hypertensive than in normotensive patients and can be reduced by antioxidant drugs [76]. Of note, in the perfused mouse kidney, DNA damage was caused by Ang II, not by induced vasoconstriction, since another vasoconstrictor did not cause DNA damage [21]. Moreover, Ang II induces genomic damage in cultured kidney cells most likely via oxidative mechanisms, which can be prevented by AT1 receptor antagonists and by antioxidants
[77]. The $2 \mathrm{~K} 1 \mathrm{C}$ mice had increased $\bullet \mathrm{O}_{2}{ }^{-}$production, which is a highly reactive and short-lived radical that is responsible for ROS generation and can interact with nearby molecules, such as DNA $[21,78,79]$; thus, our data suggest that ROS plays a key role by inducing DNA oxidative damage in this model of Ang II-dependent hypertension.

In conclusion, we demonstrated that arterial hypertension induced by endogenous RAS activation by clipping the renal artery for two weeks (the $2 \mathrm{~K} 1 \mathrm{C}$ mouse model) results in a marked increase in ROS production with consequent BM-MNC DNA damage. We speculate that Ang II effects may be due to circulating and local BM RAS; therefore, both systems may play a crucial pathobiological role in the DNA damage observed in BM-MNC of $2 \mathrm{~K} 1 \mathrm{C}$ hypertensive mice. Taking into account that BM-derived cells are responsible of maintaining, generating, and replacing differentiated cells as a consequence of physiological cell turnover or tissue damage due to injury, the data obtained by this study suggested that comorbidities, specifically Ang II-dependent hypertension, have to be particularly considered if autologous transplantation is intended, since the donor tissue (i.e., bone marrow) might be altered in its functionality.

\section{Acknowledgments}

E. C. Vasquez and S. S. Meyrelles are supported by the National Council for the Development of Science and Technology (CNPq, Refs. 302582/2011-8 and 302535/20098 Grants, resp.) and the State Agency for the Development of Science and Technology (FAPES, Ref. FAPES/PRONEX 012/2009). 


\section{References}

[1] C. Faselis, M. Doumas, and V. Papademetriou, "Common secondary causes of resistant hypertension and rational for treatment," International Journal of Hypertension, vol. 2011, Article ID 236239, 17 pages, 2011.

[2] B. V. Nogueira, Z. Palomino, M. L. Porto et al., "Granulocyte colony stimulating factor prevents kidney infarction and attenuates renovascular hypertension," Cellular Physiology and Biochemistry, vol. 29, no. 1-2, pp. 143-152, 2012.

[3] A. L. Gava, V. A. Peotta, A. M. Cabral, E. C. Vasquez, and S. S. Meyrelles, "Overexpression of eNOS prevents the development of renovascular hypertension in mice," Canadian Journal of Physiology and Pharmacology, vol. 86, no. 7, pp. 458-464, 2008.

[4] V. A. Peotta, A. L. Gava, E. C. Vasquez, and S. S. Meyrelles, "Evaluation of baroreflex control of heart rate in renovascular hypertensive mice," Canadian Journal of Physiology and Pharmacology, vol. 85, no. 8, pp. 761-766, 2007.

[5] B. V. Nogueira, V. A. Peotta, S. S. Meyrelles, and E. C. Vasquez, "Evaluation of aortic remodeling in apolipoprotein E-deficient mice and renovascular hypertensive mice," Archives of Medical Research, vol. 38, no. 8, pp. 816-821, 2007.

[6] H. F. Cheng, B. N. Becker, K. D. Burns, and R. C. Harris, "Angiotensin II upregulates type-1 angiotensin II receptors in renal proximal tubule," The Journal of Clinical Investigation, vol. 95, no. 5, pp. 2012-2019, 1995.

[7] J. N. Cohn and G. Tognoni, "A randomized trial of the angiotensin-receptor blocker valsartan in chronic heart failure," The New England Journal of Medicine, vol. 345, no. 23, pp. 1667-1675, 2001.

[8] M. Ruiz-Ortega, O. Lorenzo, M. Rupérez et al., "Role of the renin-angiotensin system in vascular diseases: expanding the field," Hypertension, vol. 38, no. 6, pp. 1382-1387, 2001.

[9] W. B. Strawn, R. S. Richmond, E. Ann Tallant, P. E. Gallagher, and C. M. Ferrario, "Renin-angiotensin system expression in rat bone marrow haematopoietic and stromal cells," British Journal of Haematology, vol. 126, no. 1, pp. 120-126, 2004.

[10] T. S. Park and E. T. Zambidis, "A role for the renin-angiotensin system in hematopoiesis," Haematologica, vol. 94, no. 6, pp. 745$747,2009$.

[11] T. C. Wu, C. Y. Chao, S. J. Lin et al., "Low-dose dextromethorphan, a NADPH oxidase inhibitor, reduces blood pressure and enhances vascular protection in experimental hypertension," PLoS ONE, vol. 7, no. 9, Article ID e46067, 2012.

[12] C. S. Ceron, M. M. Castro, E. Rizzi et al., "Spironolactone and hydrochlorothiazide exert antioxidant effects and reduce vascular matrix metalloproteinase- 2 activity and expression in a model of renovascular hypertension," British Journal of Pharmacology, vol. 160, no. 1, pp. 77-87, 2010.

[13] I. C. Haznedaroglu and M. A. Ozturk, "Towards the understanding of the local hematopoietic bone marrow renin-angiotensin system," The International Journal of Biochemistry and Cell Biology, vol. 35, no. 6, pp. 867-880, 2003.

[14] G. Salguero, E. Akin, C. Templin et al., "Renovascular hypertension by two-kidney one-clip enhances endothelial progenitor cell mobilization in a $47^{\text {phox }}$-dependent manner," Journal of Hypertension, vol. 26, no. 2, pp. 257-268, 2008.

[15] A. Sachse and G. Wolf, "Angiotensin II-induced reactive oxygen species and the kidney," Journal of the American Society of Nephrology, vol. 18, no. 9, pp. 2439-2446, 2007.
[16] G. Wolf, "Role of reactive oxygen species in angiotensin IImediated renal growth, differentiation, and apoptosis," Antioxidants and Redox Signaling, vol. 7, no. 9-10, pp. 1337-1345, 2005.

[17] P. S. Gill and C. S. Wilcox, "NADPH oxidases in the kidney," Antioxidants and Redox Signaling, vol. 8, no. 9-10, pp. 1597-1607, 2006.

[18] R. M. Touyz, "Reactive oxygen species and angiotensin II signaling in vascular cells: implications in cardiovascular disease," Brazilian Journal of Medical and Biological Research, vol. 37, no. 8, pp. 1263-1273, 2004.

[19] N. Zhong and J. Xu, "Synergistic activation of the human MnSOD promoter by DJ-1 and PGC- $1 \alpha$ : regulation by SUMOylation and oxidation," Human Molecular Genetics, vol. 17, no. 21, pp. 3357-3367, 2008.

[20] S. A. Madsen-Bouterse, Q. Zhong, G. Mohammad, Y. S. Ho, and R. A. Kowluru, "Oxidative damage of mitochondrial DNA in diabetes and its protection by manganese superoxide dismutase," Free Radical Research, vol. 44, no. 3, pp. 313-321, 2010.

[21] U. Schmid, H. Stopper, F. Schweda, N. Queisser, and N. Schupp, "Angiotensin II induces DNA damage in the kidney," Cancer Research, vol. 68, no. 22, pp. 9239-9246, 2008.

[22] L. J. Field and K. W. Gross, "Ren-1 and Ren-2 loci are expressed in mouse kidney," Proceedings of the National Academy of Sciences of the United States of America, vol. 82, no. 18, pp. 61966200, 1985.

[23] R. M. Arruda, V. A. Peotta, S. S. Meyrelles, and E. C. Vasquez, "Evaluation of vascular function in apolipoprotein E knockout mice with angiotensin-dependent renovascular hypertension," Hypertension, vol. 46, no. 4, pp. 932-936, 2005.

[24] B. P. Campagnaro, A. L. Gava, S. S. Meyrelles et al., "Cardiacautonomic imbalance and baroreflex dysfunction in the renovascular angiotensin-dependent hypertensive mouse," International Journal of Hypertension, vol. 2012, Article ID 968123, 9 pages, 2012.

[25] N. P. Singh, M. T. McCoy, R. R. Tice, and E. L. Schneider, "A simple technique for quantitation of low levels of DNA damage in individual cells," Experimental Cell Research, vol. 175, no. 1, pp. 184-191, 1988.

[26] A. R. Collins, M. Dusinska, M. Franklin et al., "Comet assay in human biomonitoring studies: reliability, validation, and applications," Environmental and Molecular Mutagenesis, vol. 30, no. 2, pp. 139-146, 1997.

[27] J. da Silva, S. M. Herrmann, V. Heuser et al., "Evaluation of the genotoxic effect of rutin and quercetin by comet assay and micronucleus test," Food and Chemical Toxicology, vol. 40, no. 7, pp. 941-947, 2002.

[28] P. Wiesel, L. Mazzolai, J. Nussberger, and T. Pedrazzini, “Twokidney, one-clip and one-kidney, one-clip hypertension in mice," Hypertension, vol. 29, no. 4, pp. 1025-1030, 1997.

[29] P. Madeddu, A. F. Milia, M. B. Salis et al., "Renovascular hypertension in bradykinin B2-receptor knockout mice," Hypertension, vol. 32, no. 3, pp. 503-509, 1998.

[30] H. Hiyoshi, K. Yayama, M. Takano, and H. Okamoto, "Angiotensin type 2 receptor-mediated phosphorylation of eNOS in the aortas of mice with two-kidney, one-clip hypertension," Hypertension, vol. 45, no. 5, pp. 967-973, 2005.

[31] E. Lazartigues, A. J. Lawrence, F. S. Lamb, and R. L. Davisson, "Renovascular hypertension in mice with brain-selective overexpression of ATla receptors is buffered by increased nitric oxide production in the periphery," Circulation Research, vol. 95, no. 5, pp. 523-531, 2004. 
[32] L. Cervenka, I. Vaneckova, Z. Huskova et al., "Pivotal role of AT1 receptors in the development of two-kidney, one-clip hypertension: study in AT1 receptor knockout mice," Journal of Hypertension, vol. 26, no. 7, pp. 1379-1389, 2008.

[33] D. Bell, E. J. Kelso, C. C. Argent et al., "Temporal characteristics of cardiomyocyte hypertrophy in the spontaneously hypertensive rat," Cardiovascular Pathology, vol. 13, no. 2, pp. 71-78, 2004.

[34] T. M. Lee, M. S. Lin, C. H. Tsai, and N. C. Chang, "Effect of pravastatin on left ventricular mass in the two-kidney, one-clip hypertensive rats," American Journal of Physiology, vol. 291, no. 6, pp. H2705-H2713, 2006.

[35] C. Oro, H. Qian, and W. G. Thomas, "Type 1 angiotensin receptor pharmacology: signaling beyond G proteins," Pharmacology and Therapeutics, vol. 113, no. 1, pp. 210-226, 2007.

[36] S. P. Barry, S. M. Davidson, and P. A. Townsend, "Molecular regulation of cardiac hypertrophy," The International Journal of Biochemistry and Cell Biology, vol. 40, no. 10, pp. 2023-2039, 2008.

[37] V. J. Dzau, "Vascular renin-angiotensin system in hypertension. New insights into the mechanism of action of angiotensin converting enzyme inhibitors," The American Journal of Medicine, vol. 84 , no. 4, pp. 4-8, 1988.

[38] I. C. Haznedaroglu, S. Tuncer, and M. Gursoy, "A local reninangiotensin system in the bone marrow," Medical Hypothesis, vol. 46, no. 6, pp. 507-510, 1996.

[39] K. E. Rodgers, S. Xiong, R. Steer et al., "Effect of angiotensin-II on hematopoietic progenitor cell proliferation," Stem Cells, vol. 18, no. 4, pp. 287-294, 2000.

[40] C. Endtman, T. Ebrahimian, T. Czech et al., "Angiotensin II impairs endothelial progenitor cell number and function in vitro and in vivo: implications for vascular regeneration," Hypertension, vol. 58, no. 3, pp. 394-403, 2011.

[41] H. Kato, J. Ishida, S. Imagawa et al., "Enhanced erythropoiesis mediated by activation of the renin-angiotensin system via angiotensin II type 1A receptor," The FASEB Journal, vol. 19, no. 14, pp. 2023-2025, 2005.

[42] S. de la Iglesia Inigo, C. E. López-Jorge, M. T. Gómez-Casares et al., "Induction of apoptosis in leukemic cell lines treated with captopril, trandolapril and losartan: a new role in the treatment of leukaemia for these agents," Leukemia Research, vol. 33, no. 6, pp. 810-816, 2009.

[43] A. Ismail, H. Khosravi, and H. Olson, "The tole of infection in atherosclerosis and coronary artery disease: a new therapeutic target," Heart Disease, vol. 1, no. 4, pp. 233-240, 1999.

[44] M. Ruiz-Ortega, O. Lorenzo, Y. Suzuki, M. Rupérez, and J. Egido, "Proinflammatory actions of angiotensins," Current Opinion in Nephrology and Hypertension, vol. 10, no. 3, pp. 321329, 2001.

[45] K. M. Schmidt-Ott, S. Kagiyama, and M. I. Phillips, "The multiple actions of angiotensin II in atherosclerosis," Regulatory Peptides, vol. 93, no. 1-3, pp. 65-77, 2000.

[46] U. Rueckschloss, M. T. Quinn, J. Holtz, and H. Morawietz, "Dose-dependent regulation of $\mathrm{NAD}(\mathrm{P}) \mathrm{H}$ oxidase expression by angiotensin II in human endothelial cells: protective effect of angiotensin II type 1 receptor blockade in patients with coronary artery disease," Arteriosclerosis, Thrombosis, and Vascular Biology, vol. 22, no. 11, pp. 1845-1851, 2002.

[47] M. E. Pueyo, W. Gonzalez, A. Nicoletti, F. Savoie, J. F. Arnal, and J. B. Michel, "Angiotensin II stimulates endothelial vascular cell adhesion molecule-1 via nuclear factor- $\kappa \mathrm{B}$ activation induced by intracellular oxidative stress," Arteriosclerosis, Thrombosis, and Vascular Biology, vol. 20, no. 3, pp. 645-651, 2000.
[48] L. A. Cassis, D. L. Rateri, H. Lu, and A. Daugherty, "Bone marrow transplantation reveals that recipient ATla receptors are required to initiate angiotensin II-induced atherosclerosis and aneurysms," Arteriosclerosis, Thrombosis, and Vascular Biology, vol. 27, no. 2, pp. 380-386, 2007.

[49] J. Fandrey, "Oxygen-dependent and tissue-specific regulation of erythropoietin gene expression," American Journal of Physiology, vol. 286, no. 6, pp. R977-R988, 2004.

[50] V. da Cunha, D. M. Tham, B. Martin-McNulty et al., "Enalapril attenuates angiotensin II-induced atherosclerosis and vascular inflammation," Atherosclerosis, vol. 178, no. 1, pp. 9-17, 2005.

[51] T. D. Giles, G. E. Sander, B. D. Nossaman et al., "Impaired vasodilation in the pathogenesis of hypertension: focus on nitric oxide, endothelial-derived hyperpolarizing factors and prostaglandins," Journal of Clinical Hypertension, vol. 14, no. 4, pp. 198-205, 2012.

[52] S. R. Khan, "Is oxidative stress a link between nephrolithiasis and obesity, hypertension, diabetes, chronic kidney disease, metabolic syndrome?" Urological Research, vol. 40, no. 2, pp. 95-112, 2012.

[53] A. C. Montezano and R. M. Touyz, "Molecular mechanisms of hypertension-reactive oxygen species and antioxidants: a basic science update for the clinician," The Canadian Journal of Cardiology, vol. 28, no. 3, pp. 188-195, 2012.

[54] R. R. Campos, E. B. Oliveira-Sales, E. E. Nishi, M. A. Boim, M. S. Dolnikoff, and C. T. Bergamaschi, "The role of oxidative stress in renovascular hypertension," Clinical and Experimental Pharmacology and Physiology, vol. 38, no. 2, pp. 144-152, 2011.

[55] Y. C. Chan and O. S. Leung, "The renin-angiotensin system and reactive oxygen species: implications in pancreatitis," Antioxidants and Redox Signaling, vol. 15, no. 10, pp. 2743-2755, 2011.

[56] E. B. Oliveira-Sales, E. E. Nishi, B. A. Carillo et al., "Oxidative stress in the sympathetic premotor neurons contributes to sympathetic activation in renovascular hypertension," American Journal of Hypertension, vol. 22, no. 5, pp. 484-492, 2009.

[57] V. A. Braga, I. A. Medeiros, T. P. Ribeiro et al., "Angiotensin II-induced reactive oxygen species along the SFO-PVN-RVLM pathway: implications in neurogenic hypertension," Brazilian Journal of Medical and Biological Research, vol. 44, no. 9, pp. 871-876, 2011.

[58] S. Wind, K. Beuerlein, T. Eucker et al., "Comparative pharmacology of chemically distinct NADPH oxidase inhibitors," British Journal of Pharmacology, vol. 161, no. 4, pp. 885-898, 2010.

[59] R. A. Beswick, A. M. Dorrance, R. Leite, and R. C. Webb, "NADH/NADPH oxidase and enhanced superoxide production in the mineralocorticoid hypertensive rat," Hypertension, vol. 38, no. 5, pp. 1107-1111, 2001.

[60] A. D. Dobrian, S. D. Schriver, and R. L. Prewitt, "Role of angiotensin II and free radicals in blood pressure regulation in a rat model of renal hypertension," Hypertension, vol. 38, no. 3, pp. 361-366, 2001.

[61] K. K. Griendling, C. A. Minieri, J. D. Ollerenshaw, and R. W. Alexander, "Angiotensin II stimulates NADH and NADPH oxidase activity in cultured vascular smooth muscle cells," Circulation Research, vol. 74, no. 6, pp. 1141-1148, 1994.

[62] Y. Higashi, S. Sasaki, K. Nakagawa, H. Matsuura, T. Oshima, and K. Chayama, "Endothelial function and oxidative stress in renovascular hypertension," The New England Journal of Medicine, vol. 346, no. 25, pp. 1954-1962, 2002. 
[63] R. M. Touyz, F. Tabet, and E. L. Schiffrin, "Redox-dependent signalling by angiotensin II and vascular remodelling in hypertension," Clinical and Experimental Pharmacology and Physiology, vol. 30, no. 11, pp. 860-866, 2003.

[64] Y. Álvarez, A. M. Briones, R. Hernanz, J. V. Pérez-Girón, M. J. Alonso, and M. Salaices, "Role of NADPH oxidase and iNOS in vasoconstrictor responses of vessels from hypertensive and normotensive rats," British Journal of Pharmacology, vol. 153, no. 5, pp. 926-935, 2008.

[65] K. K. Griendling and G. A. Fitzgerald, "Oxidative stress and cardiovascular injury-part I: basic mechanisms and in vivo monitoring of ROS," Circulation, vol. 108, no. 16, pp. 1912-1916, 2003.

[66] K. K. Griendling and G. A. Fitzgerald, "Oxidative stress and cardiovascular Injury-part II: animal and human studies," Circulation, vol. 108, no. 17, pp. 2034-2040, 2003.

[67] S. Kimura, G. X. Zhang, and Y. Abe, "Malfunction of vascular control in lifestyle-related diseases: oxidative stress of angiotensin II-induced hypertension: mitogen-activated protein kinases and blood pressure regulation," Journal of Pharmacological Sciences, vol. 96, no. 4, pp. 406-410, 2004.

[68] T. Imanishi, T. Hano, and I. Nishio, "Angiotensin II accelarates endothelial progenitor cell senescence through induction of oxidative stress," Journal of Hypertension, vol. 23, no. 1, pp. 97104, 2005.

[69] T. J. Guzik, N. E. Hoch, K. A. Brown et al., "Role of the T cell in the genesis of angiotensin II-induced hypertension and vascular dysfunction," Journal of Experimental Medicine, vol. 204, no. 10, pp. 2449-2460, 2007.

[70] M. Valko, C. J. Rhodes, J. Moncol, M. Izakovic, and M. Mazur, "Free radicals, metals and antioxidants in oxidative stressinduced cancer," Chemico-Biological Interactions, vol. 160, no. 1, pp. 1-40, 2006.

[71] B. Halliwell and O. I. Aruoma, "DNA damage by oxygenderived species. Its mechanism and measurement in mammalian systems," FEBS Letters, vol. 281, no. 1-2, pp. 9-19, 1991.

[72] M. G. Andreassi, N. Botto, S. Simi et al., "Diabetes and chronic nitrate therapy as co-determinants of somatic DNA damage in patients with coronary artery disease," Journal of Molecular Medicine, vol. 83, no. 4, pp. 279-286, 2005.

[73] J. K. Folkmann, S. Loft, and P. Møller, "Oxidatively damaged DNA in aging dyslipidemic ApoE ${ }^{-}$and wild-type mice," Mutagenesis, vol. 22, no. 2, pp. 105-110, 2007.

[74] S. P. Dalboni, B. P. Campagnaro, C. L. Tonini et al., "The concurrence of hypercholesterolemia and aging promotes DNA damage in apolipoprotein E-deficient mice," Open Journal of Blood Diseases, vol. 2, pp. 51-55, 2012.

[75] N. Schupp, P. Kolkhof, N. Queisser et al., "Mineralocorticoid receptor-mediated DNA damage in kidneys of DOCA-salt hypertensive rats," The FASEB Journal, vol. 25, no. 3, pp. 968978, 2011.

[76] J. Lee, M. Lee, J. U. Kim, K. I. Song, Y. S. Choi, and S. S. Cheong, "Carvedilol reduces plasma 8-hydroxy-2' -deoxyguanosine in mild to moderate hypertension: a pilot study," Hypertension, vol. 45, no. 5, pp. 986-990, 2005.

[77] N. Schupp, U. Schmid, P. Rutkowski et al., "Angiotensin IIinduced genomic damage in renal cells can be prevented by angiotensin II type 1 receptor blockage or radical scavenging," American Journal of Physiology, vol. 292, no. 5, pp. F1427-F1434, 2007.
[78] J. Cadet, T. Douki, D. Gasparutto, and J. L. Ravanat, “Oxidative damage to DNA: formation, measurement and biochemical features," Mutation Research, vol. 531, no. 1-2, pp. 5-23, 2003.

[79] J. Chen, W. Chen, M. Zhu et al., "Propofol attenuates angiotensin II-induced apoptosis in human coronary artery endothelial cells," British Journal of Anaesthesia, vol. 107, no. 4, pp. 525532, 2012. 


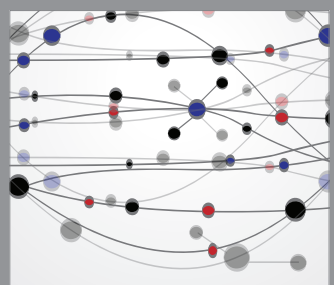

The Scientific World Journal
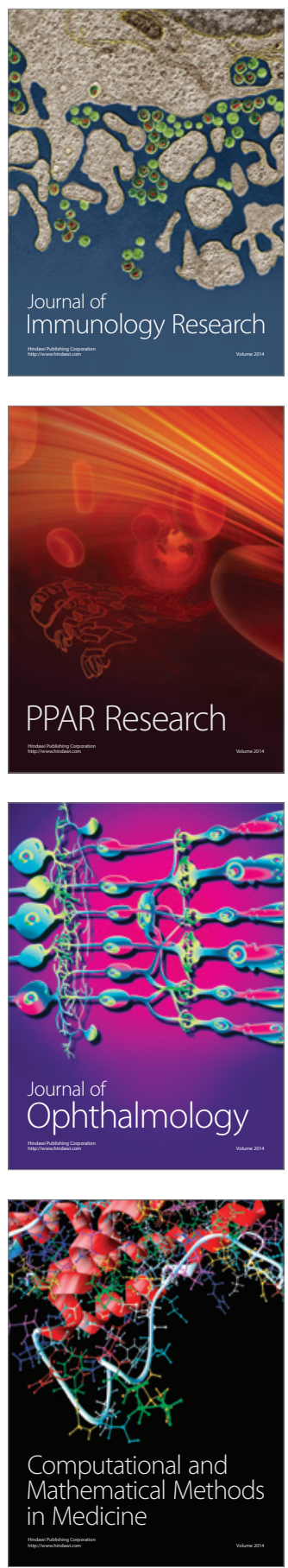

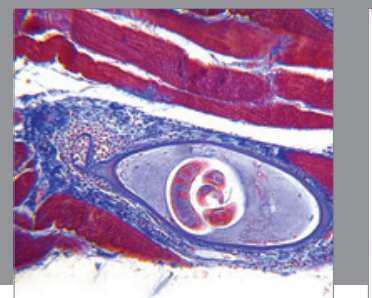

Gastroenterology

Research and Practice
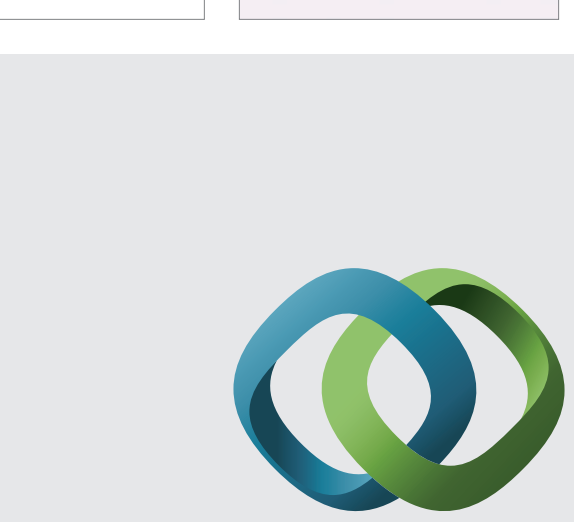

\section{Hindawi}

Submit your manuscripts at

http://www.hindawi.com
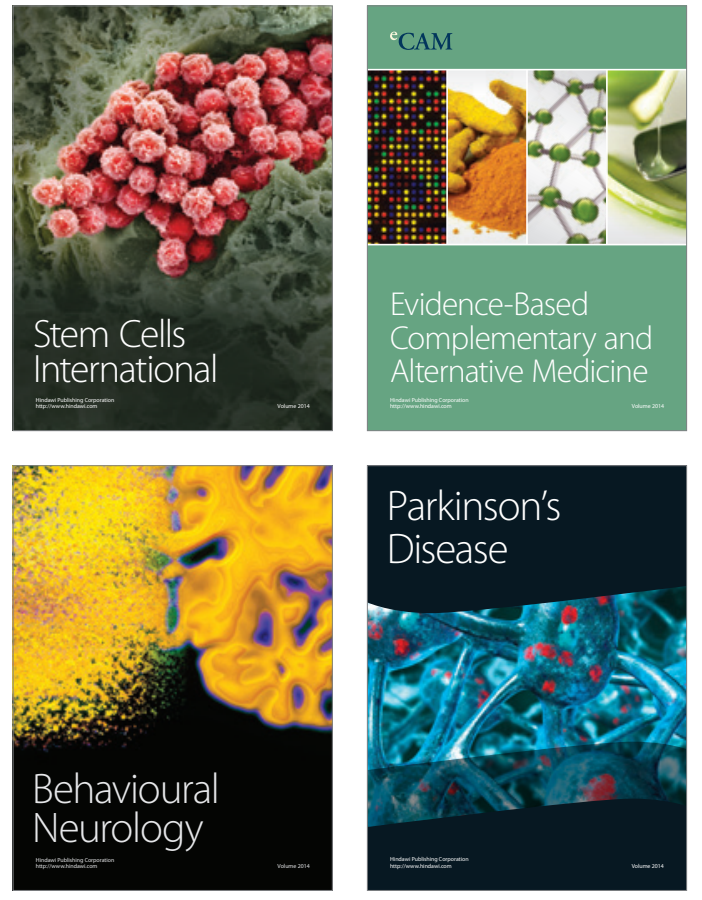
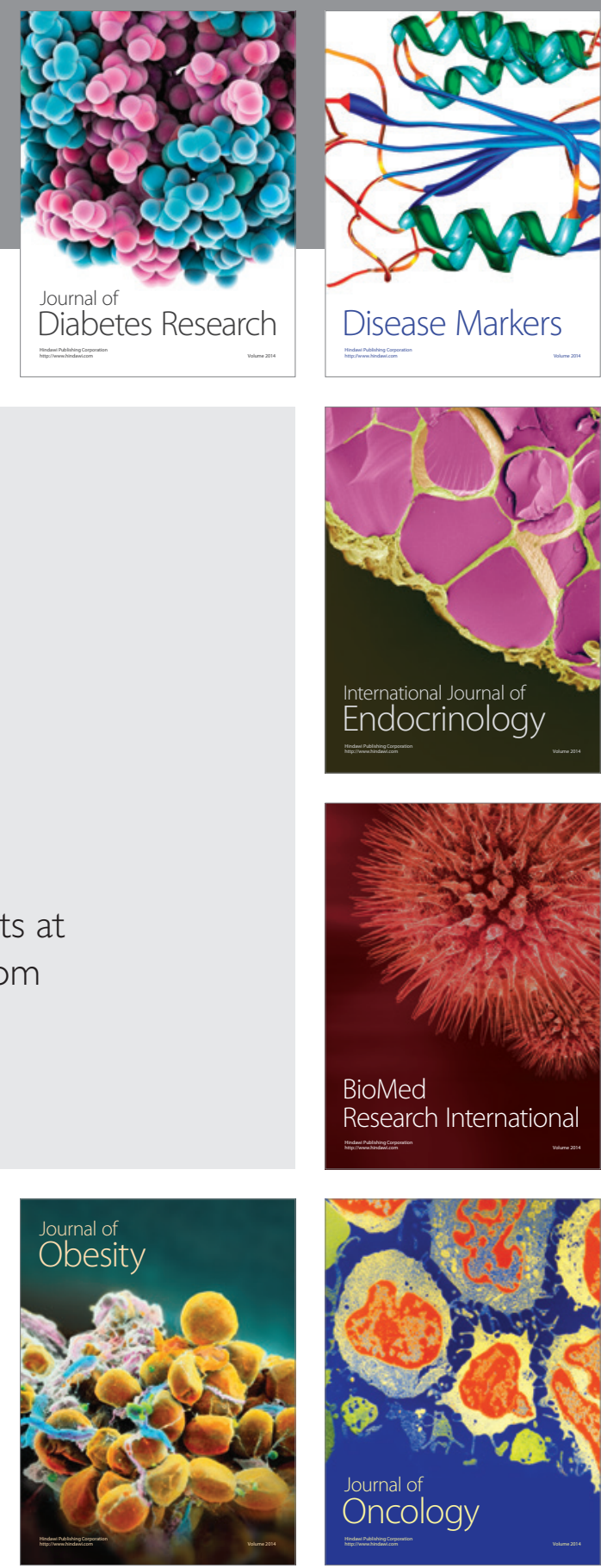

Disease Markers
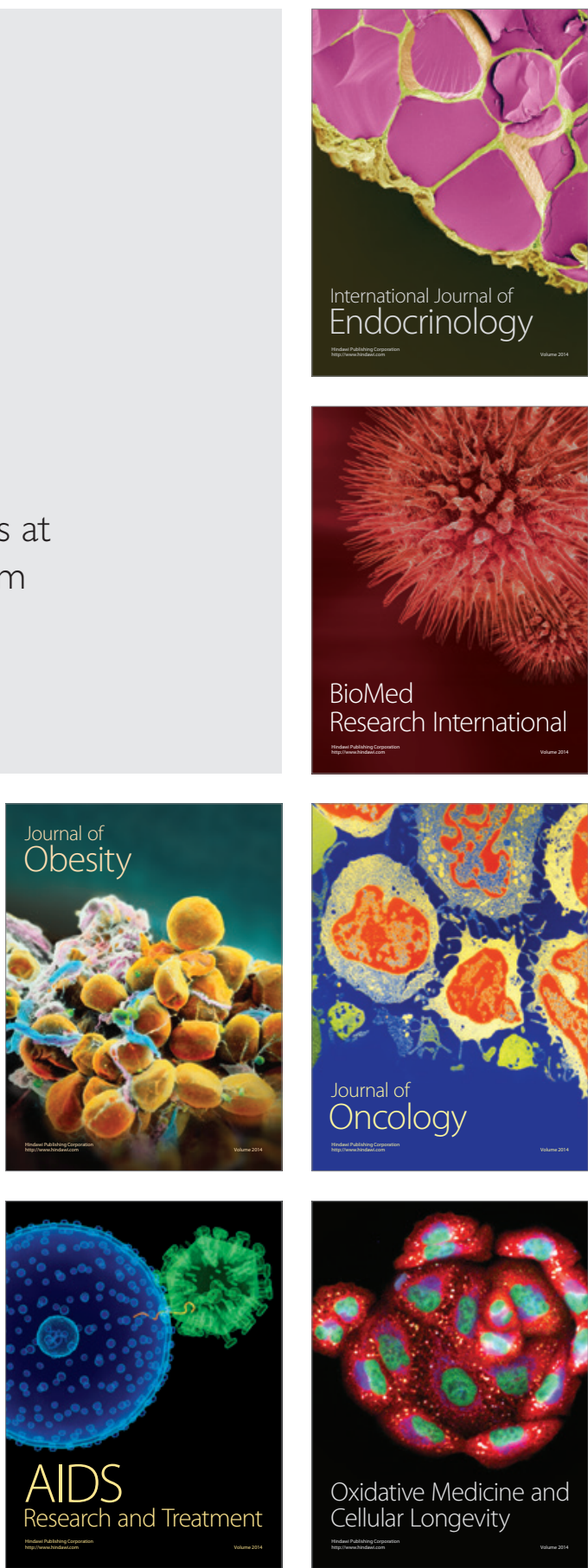